\title{
Effect on Brand Loyalty in Mobile Phone Purchasing (A Case Study in Bahawalpur, Pakistan)
}

\author{
Hafiz Muhammad Wasif Rasheed \\ Visiting Lecturer, Department of Management Sciences \\ The Islamia University of Bahawalpur, Pakistan \\ Email: wasifrasheed211@gmail.com \\ Muhammad Khalid Anser \\ Scholar Shaanxi Normal University, Xian, China \\ Email: khalidsnnu@yahoo.com
}

Received: January 24, 2017 Accepted: February 15, 2017 Published: April 05, 2017

doi:10.5296/jpag.v7i1.11042 URL: http://dx.doi.org/10.5296/jpag.v7i1. 11042

\begin{abstract}
Brands are the key to sales increase in consumer markets. They make a relationship between the consumers and the company. Brand loyalty is a consumer's preference to purchase a particular product or service at first or repeatedly in a competitive market. The general purpose of this study is to investigate the factors leading to brand loyalty in service sector. Specifically, we are concerned to observe the factors affecting brand loyalty in mobile phone purchasing in Bahawalpur, Pakistan. The sample size of 150 is taken through convenient sampling method. The survey method is used to collect the data from the respondents through self-administered questionnaire. The regression analysis approved the significant positive relationship of the proposed factors with brand loyalty.
\end{abstract}

Keywords: Brand Loyalty, Customer Satisfaction, perceived Quality, Brand Communication, Brand Trust 


\section{Introduction}

Today, the markets are very much mature, the organizations find it very difficult to retain and attract the prosperous customers due to intense competition. The advancement in technology, the saturation of markets, globalization and intense competition has urged the companies to focus more and more on brand loyalty. For this, we find an attractive space to conduct research on this burning issue. These factors urge us to have conducted a research on some of the most influential antecedents of brand loyalty namely perceived quality, customer satisfaction. The brand communication and customer satisfaction put an effect on Brand trust that ultimately leads to brand loyalty. The study is conducted to explore the relationship of previously described variables with brand loyalty so that explaining how they create brand loyalty with their collective impact. We selected mobile phone sector of Pakistan to test these variables whether they have the effect on the brand loyalty as proposed. The mobile phone sector is one of the fastest growing sectors in Pakistan. According to a recent study, there are almost 80 million mobile phone users in Pakistan and yet the number is growing rapidly. It is predicted that after 10 years or less, every second Pakistani will have a mobile phone.

In modern marketing world, the brand is a term, symbol, name, logo, design or combination of them that differentiates any product or service from those of competitors' (Kotler, 1997).In previous researches, the researchers had been taking the measure of repurchase behavior as brand loyalty but in recent days, measuring true loyalty is the best way of measuring brand loyalty (Bennett and Rundle-Thiele, 2000). Two indicators are added by Day (1996) affection and action for brand loyalty and divided brand loyalty into spurious brand loyalty and actual brand loyalty. In spurious brand loyalty, the consumer has no other choice of brand except the current one but in actual brand loyalty, the consumer shows a firm attitudinal and psychological binding with the specific product or service among the other similar brands.

The past researches show that trust is very essential for the development of brand loyalty (Berry, 1995; Reicheld\&Schefter, 2000; Dyson, Farr \& Hollis, 1996; Morgan and Hunt 1994, Chaudhuri and Holbrook, 2001). Consumers trust in brand is based on positive beliefs regarding the expectations of the consumers in a product or service.

A brand name is just like a trade mark developing a brand name is an expensive process (Kohli and Thakor, 1997). It is very necessary that brand name must be easy to remember and should be very unique (Keller, 2008). The brand name causes a competitive advantage over competitors (Zeugner -Roth, et al., 2008). Consumers perceive the products from an overall perspective, relating with the brand name, all the characteristics and satisfaction observed by the purchase and use of the product.

The brand communication is the first and foremost element in managing brand relationship with the consumers (Panda, 2004, p.9). The brand communication is also very important in launching new products (Pearson, 1996; Duncan and Moriarty, 1998). Brand communication has been consistently found to play an important role in creating positive brand attitudes (Kempf and Smith,1998).

A number of empirical studies show that customer satisfaction plays a very important role in 
developing repurchase behavior (Bennett et al., 2007, et al., 1999; Russell Oliver, 1980; Pritchard). Satisfaction increases loyalty when brand loyalty is measured in a number of successive purchases of the same brand (LaBarbera and Mazursky, 1983).

The degree of excellence of a product or service is called quality. It is also defined as fitness for purpose. The product quality also differentiates the product or service in competitive world (Zeithaml, 1988, Aaker, 1996; Yoo, Donthu, \& Lee, 2000; Low \& Lamb, 2000). when firms identify then satisfy the needs, wants and demands of customers, they find a positional advantage over competitors as reflected in growing sales and building loyal customers (Hult and Ketchen, 2001; Zhu and Nakata, 2007).

The results of our research show that there is a strong positive relationship between the brand loyalty and the independent variables of our proposed model. This research will open the doors for future researchers to understand and explore the markets in terms of brand loyalty. This research will provide a better understandability of the customers and markets for the organizations competing in such a mature and intensive competitive market.

\section{Literature Review}

\subsection{Brand Loyalty}

The brand loyalty is most completely defined by Jacoby and Olson (1970). They define brand loyalty as the mental purchase process resulted from nonrandom and long existence behavior of the customers. In simple words, we can say that brand loyalty is a repurchase behavior of customers towards a specific product or service. The consideration of brand loyalty is concerned when a customer has choice among various brands. In previous researches, the researchers had been taking the measure of repurchase behavior as brand loyalty but in recent days, measuring true loyalty is the best way of measuring brand loyalty (Bennett and Rundle-Thiele, 2000). It is observed that brand loyalty covers both affective loyalty and action loyalty simultaneously (Baldinger and Rubinson) (1996). The affective loyalty Groth and McDaniel (1993) confirmed that affective loyalty shows consumer loyalty to a specific brand all the way. Oliver (1999) classified brand loyalty into four parts: cognitive loyalty, affective loyalty, conation loyalty and action loyalty. There are so many factors that lead to brand loyalty. Two indicators are added by Day (1996) affection and action for brand loyalty and divided brand loyalty into spurious brand loyalty and actual brand loyalty. In spurious brand loyalty, the consumer has no other choice of brand except the current one but in actual brand loyalty, the consumer shows a firm attitudinal and psychological binding with the specific product or service among the other similar brands. The advancement in technology, the saturation of markets, globalization and intense competition has urged the companies to focus more and more on brand loyalty. So brand loyalty may confirm the organizational growth and above average profits. In simple words, we can say that the purpose of brand loyalty is to attract new customers and retaining the old loyal customers. 


\subsection{Brand Trust}

The willingness of the consumer to depend on the ability of the brand to perform its prescribed functions is called brand trust (Moormal et al 1993, p. 315). The brand trust is an intentional confidence shown by the consumer on a specific product or service to exchange the partner's trustworthiness (Dwyer and LaGace., 1986). Doney and Cannon (1997), Zaltman, and Deshpande (1992) proposed that trust is only relevant in the situation of uncertainty. The consumers rely on the trusted brands only.

There are different fields of studies in which trust has been very important in proving the relationships such as sociology (e.g., Lewis and Weigert 1985), economics (e.g., Dasgupta 1988), psychology (e.g., Deutsch 1960; Larzelere and Huston 1980; Rempel et al. 1985; Rotter 1980), management (e.g., Barney and Hausen 1994) and marketing (e.g., Andaleeb 1992; Dwyer et al. 1987; Morgan and Hunt 1994). The past researches show that trust is very essential for the development of brand loyalty (Berry, 1995; Reicheld \& Schefter, 2000; Dyson, Farr \& Hollis, 1996; Morgan and Hunt 1994, Chaudhuri and Holbrook, 2001). In marketing, the brand trust has got a great attention (Schurr, \& Oh, 1987, Andaleeb, 1992; Dwyer,; Morgan \& Hunt, 1994).

Barney and Hansen (1994) confirmed that trust is the mutual confidence that no party in an exchange will exploit another's vulnerability. Consumers trust in brand is based on positive beliefs regarding the expectations of the consumers in a product or service.

\subsection{Brand Communication}

The brand communication is the process of decreasing the gap between the consumer and his/her perception regarding the product and service. The purpose of brand communication is exposing the product or service to the audience so that the consumer would be fully aware of the product or service present in the market. Extensive advertising campaigns through print and electronic media is used for brand communication. The brand communication is the first and foremost element in managing brand relationship with the consumers (Panda, 2004, p.9). The brand communication is also very important in launching new products (Pearson, 1996; Duncan and Moriarty, 1998). Brand communication has been consistently found to play an important role in creating positive brand attitudes (Kempf and Smith, 1998).

\subsection{Customer Satisfaction}

The customer satisfaction is the term widely used in marketing. It is a measure to identify how the product or service meets the expectations of the consumers regarding a particular product or service. A number of empirical studies show that customer satisfaction plays a very important role in developing repurchase behavior (Bennett et al., 2007, et al., 1999; Russell Oliver, 1980; Pritchard -). Satisfaction increases loyalty when brand loyalty is measured in a number of successive purchases of the same brand (LaBarbera and Mazursky, 1983). The customer satisfaction can be both cognitive and emotional, Rodriguez Del Bosque and San Martin (2008). There are two common formulations of satisfaction: overall satisfaction and transaction specific satisfaction. Whenever, there is an immediate post purchase evaluation it is termed as post purchase satisfaction (Oliver,1993). The overall 


\section{Macrothink}

satisfaction is the judgment of all the parameters of expectations and the actual satisfaction from a particular product or service (Bitner\&Hubbert, 1994).

\subsection{Perceived Product Quality}

The degree of excellence of a product or service is called quality. It is also defined as fitness for purpose. The product quality also differentiates the product or service in competitive world (Zeithaml, 1988, Aaker, 1996; Yoo, Donthu, \& Lee, 2000; Low \& Lamb, 2000). There are so many dimensions of product or service quality (Chao, 2008). The Nordic School's view of service quality consists of two dimensions: functional quality and technical quality and (Gronroos, 1984). On the other hand, when firms identify then satisfy the needs, wants and demands of customers, they find a positional advantage over competitors as reflected in growing sales and building loyal customers (Hult and Ketchen, 2001; Zhu and Nakata, 2007). One reason is that customers perceive that the firm offers greater value in its products and services. As satisfied customers are likely to be loyal, the notion of positional advantage suggests that greater customer orientation corresponds with the reinforcement of the link between satisfaction and loyalty.

\section{Hypothesis and Model}

\subsection{Hypothesis}

H1: There is a significant relationship between perceived quality \& customer satisfaction.

H2: There is a significant relationship between brand communication \& brand trust.

H3: There is a significant relationship between customer satisfaction \& brand loyalty

H4: There is a significant relationship between brand trust and Brand Loyalty.

H5: There is a significant relationship between perceived quality and brand loyalty.

H6: There is a significant relationship between brand communication\& brand loyalty

H7: There is a significant relationship between Customer satisfaction and Brand Trust. 


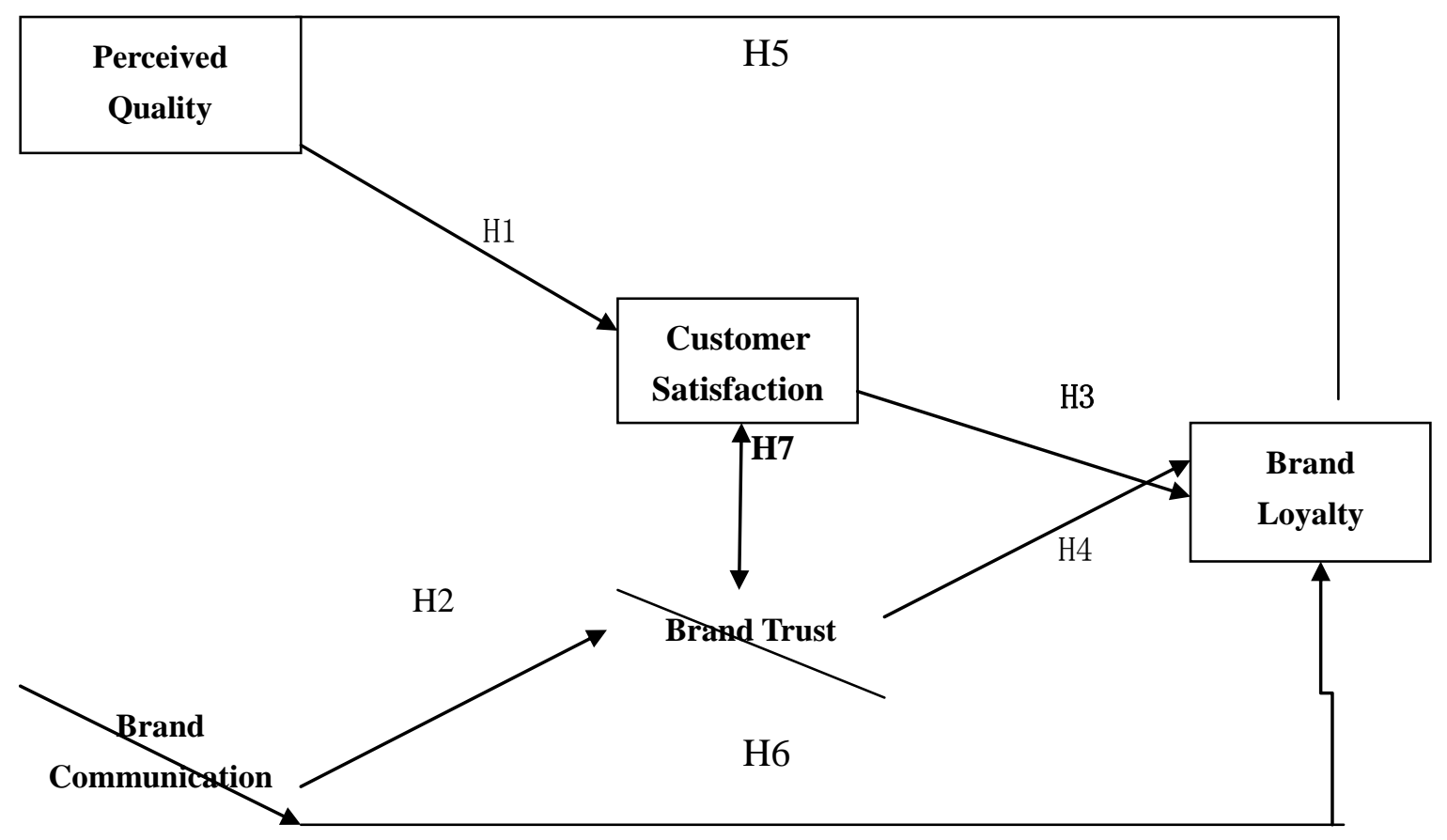

\section{Research Methodology}

The causal research in social sciences is very important. This research is causal in nature. The causal research defines the relationship between two variables. The causal research in marketing identifies the cause and effect between people. The objective of the causal research is to determine which variable might be causing a certain behavior i.e. whether there is a cause and effect relationship between variables. This type of research is very complex and the researcher is never completely certain that there are no other factors that influencing the causal relationship especially when dealing with people's attitude and motivations.

\subsection{Sample/Data}

We collected data in five different cellular phone users from the customers in Bahawalpur (Pakistan). Those mobile users were focused who have been using the services for at least three years.

The convenient sampling technique is used to collect the data. In convenience sampling technique, the relevant information is conveniently available (Zikmund, 1997).

A self-administered questionnaire was distributed among 180 mobile phone users in the locality of Bahawalpur City (Pakistan). Out of these 30questionnaires were found incomplete or not responded. So the final sample size for this particular study is 150 .

It has ensured that the sample members possess the two basic qualifications to participate in the self-administered questionnaire. First, the sample member should be using mobile phone service for at least three years. Second, he should be using only the one cellular phone service 


\section{Macrothink

at a time during the said time period.

\subsection{Instruments and Measures}

The instruments and measures is an important part of the survey method. The instrument and measures of the current study focuses two major purposes: First, the relationship of different variables in brand loyalty or cellular phone users. Second, the information about different characteristics of the respondents that can be used to measure the variations in different categories is collected. The second part includes the variables that we are going to measure in our study Table 1. These variables include Brand loyalty, Perceived Quality, Customer Satisfaction, Brand Trust, and Brand Communication. All these variables are derived from the past researches and literatures. The variable of Customer Satisfaction has two items, perceived quality and brand name have four items each and Brand Trust and Brand Communication have five items each. 


\section{Macrothink}

Table 1: Scales of the Study

\begin{tabular}{|c|c|c|c|}
\hline No. & Variable & Items & Reference \\
\hline 01 & Brand Loyalty & $\begin{array}{l}\text { 1. This Brand would be my first choice. } \\
\text { 2. I feel myself to be loyal to this Brand } \\
\text { 3. I will not switch to other mobile Phone if } \\
\text { the same brand is available in the market. }\end{array}$ & $\begin{array}{l}\text { Youn et, al } \\
2000\end{array}$ \\
\hline 02 & $\begin{array}{l}\text { Perceived } \\
\text { Quality }\end{array}$ & $\begin{array}{l}\text { 1. It is likely that this mobile phone is of } \\
\text { very high quality. } \\
\text { 2. It is likely that this mobile phone is of } \\
\text { very consistent quality. } \\
\text { 3. It is likely that this mobile phone offers } \\
\text { excellent features. } \\
\text { 4. It is likely that this mobile phone is very } \\
\text { reliable. }\end{array}$ & $\begin{array}{c}\text { Yoo, } \\
\text { Donthu, \& } \\
\text { Lee, } 2000\end{array}$ \\
\hline 03 & $\begin{array}{l}\text { Customer } \\
\text { Satisfaction }\end{array}$ & $\begin{array}{l}\text { 1. Over all I am satisfied with specific } \\
\text { experience of this mobile phone. } \\
\text { 2. I am satisfied with my decision to } \\
\text { purchase this mobile phone. }\end{array}$ & $\begin{array}{l}\text { Bennett et } \\
\text { al., } 2007\end{array}$ \\
\hline 04 & Brand Trust & $\begin{array}{l}\text { 1. I trust this mobile phone. } \\
\text { 2. I rely on this mobile phone. } \\
\text { 3. This mobile phone is safe as it maintains } \\
\text { and ensures my confidentiality and } \\
\text { privacy. } \\
\text { 4. This is an honest brand as it charges fairly } \\
\text { on its services\& features. } \\
\text { 5. This mobile phone meets my } \\
\text { expectations. }\end{array}$ & $\begin{array}{l}\text { Chaudhuri } \\
\text { and } \\
\text { Holbrook, } \\
2001\end{array}$ \\
\hline 05 & $\begin{array}{l}\text { Brand } \\
\text { Communication }\end{array}$ & $\begin{array}{l}\text { 1. I react favorably to the advertising and } \\
\text { promotion of this mobile phone. } \\
\text { 2. I feel positive towards the advertising and } \\
\text { persona of this brand. } \\
\text { 3. The advertising and promotions of this } \\
\text { brand are very informative and appealing. } \\
\text { 4. I am happy with the advertising and } \\
\text { promotions of this mobile service. } \\
\text { 5. I like the advertising and promotions of } \\
\text { this mobile phone. }\end{array}$ & Panda, 2004, \\
\hline
\end{tabular}




\subsection{Procedure}

The proposed questionnaire was distributed among 180 respondents in Bahawalpur, Pakistan. These respondents were selected on the basis of the criteria discussed earlier. Before giving the questionnaire to the respondents, the purpose of our study was communicated to the respondents so that they could easily fill in the questionnaire without any ambiguity. A total of 150 respondents responded positively and rest of the questionnaires was not included in further analysis as they were found incomplete. After having completed the questionnaires, these questionnaires were coded and entered into SPSS Software sheet for further statistical analysis.

\subsection{Reliability Analysis}

Table 2: Reliability of Measurements Instrument.

\begin{tabular}{|l|l|l|}
\hline Scales & Items & Cronbach's Alpha \\
\hline Brand Loyalty & 3 & 0.627 \\
Perceived Quality & 4 & 0.701 \\
Customer Satisfaction & 2 & 0.715 \\
Brand Trust & 5 & 0.749 \\
Brand Communication & 5 & 0.827 \\
\hline
\end{tabular}

\section{Results of Analysis}

Table: 2 Profile of the respondents

\begin{tabular}{|c|c|c|c|}
\hline Variable & Category & Frequency & Percentage \\
\hline Gender & $\begin{array}{l}\text { Male } \\
\text { Female }\end{array}$ & $\begin{array}{l}101 \\
49\end{array}$ & $\begin{array}{l}67.3 \\
32.7\end{array}$ \\
\hline Status & $\begin{array}{l}\text { Student } \\
\text { Employed } \\
\text { Unemployed } \\
\text { Self Employed } \\
\text { House Wife }\end{array}$ & $\begin{array}{l}76 \\
49 \\
9 \\
9 \\
7\end{array}$ & $\begin{array}{l}50.7 \\
32.7 \\
6 \\
6 \\
4.7\end{array}$ \\
\hline Education & Matriculation & 6 & 4 \\
\hline
\end{tabular}




\begin{tabular}{|c|c|c|c|}
\hline & $\begin{array}{l}\text { Inter } \\
\text { Graduation } \\
\text { Master } \\
\text { M.Phil./PhD }\end{array}$ & $\begin{array}{l}8 \\
51 \\
70 \\
15\end{array}$ & $\begin{array}{l}5.3 \\
34 \\
46.7 \\
10\end{array}$ \\
\hline Income (Rs) & $\begin{array}{l}\text { Below } 15000 \\
15000-25000 \\
25000-35000 \\
35000-45000 \\
\text { Above } 45000 \\
\text { Missing }\end{array}$ & $\begin{array}{l}44 \\
21 \\
18 \\
14 \\
25 \\
28\end{array}$ & $\begin{array}{l}29.3 \\
14 \\
12 \\
9.3 \\
16.7 \\
18.7\end{array}$ \\
\hline Age & $\begin{array}{l}\text { 15-20 Years } \\
\text { 20-25 Years } \\
\text { 25-30 Years } \\
\text { Above } 30 \text { Years }\end{array}$ & $\begin{array}{l}11 \\
68 \\
32 \\
39\end{array}$ & $\begin{array}{l}7.3 \\
45.3 \\
21.3 \\
26\end{array}$ \\
\hline $\begin{array}{l}\text { Cellular } \\
\text { Phone Brands }\end{array}$ & $\begin{array}{l}\text { Samsung } \\
\text { Nokia } \\
\text { Sony } \\
\text { HTC } \\
\text { China Mobiles } \\
\text { Others }\end{array}$ & $\begin{array}{l}35 \\
59 \\
23 \\
18 \\
15 \\
0\end{array}$ & $\begin{array}{l}23.3 \\
39.3 \\
15.3 \\
12 \\
10 \\
0\end{array}$ \\
\hline
\end{tabular}

\subsection{Hypothesis Testing}

\subsubsection{Perceived Quality, Customer Satisfaction and Brand Loyalty}

The regression results of the study confirm the significant relationship of brand name and brand communication on brand trust. The Beta values of Perceived quality, Customer Satisfaction and Brand Loyalty are respectively $(\beta=0.354),(\beta=0.256)$ and the significant values are $(p<0.001),(p<0.01)$. The value of Adjusted $R$ Square for the above relation is 0.251 .

From the above analysis, the hypothesis $\mathrm{H} 2$ and $\mathrm{H} 3$ are proved. 


\subsubsection{Brand Communication, Brand trust and Brand Loyalty}

The regression estimates of the current research confirm the significant positive relationship of perceived quality on customer satisfaction. The statistical figures of Beta value and Significant value are $(\beta=0.442),(p<0.001)$ respectively. The adjusted $R$ square of this relationship is 0.190 . So our study approves $\mathrm{H} 1$.

\subsubsection{Perceived Quality and Brand Loyalty}

The regression results of the research represent a significant positive relationship between perceived quality and brand trust. The Beta value is $(\beta=0.277)$ with significant value of $(p<$ 0.01). So, $\mathrm{H} 4$ is also supported. There is also found a significant positive relationship between customer satisfaction and brand loyalty. The Beta value of this relation is $(\beta=0.267)$, having significant value $(\mathrm{p}<0.01)$. Hence, H5 is also proved. Similarly, there have observed a significant positive relationship between brand trust and brand loyalty. The beta value of this relation is $(\beta=0.187),(p<0.05)$. Therefore, H6 is accepted by this study. The adjusted $R$ square of above relationships is 0.321 .

\subsubsection{Brand Communication and Brand Loyalty}

The regression estimates of the current research confirm the significant positive relationship of perceived quality on customer satisfaction. The statistical figures of Beta value and Significant value are $(\beta=0.442),(p<0.001)$ respectively. The adjusted $R$ square of this relationship is 0.190 . So our study approves $\mathrm{H} 1$.

\section{Conclusion}

Our research strongly approved the proposed hypothesis of our research model. It is concluded from our research that perceived quality; customer satisfaction and brand trust collectively lead to brand loyalty. The regression analysis of these variables demonstrates a strong relationship between the said variables and brand loyalty. This study also approved that brand name and brand communication are the constructs of brand trust that ultimately lead to brand loyalty.

\section{Limitations}

As this research is based on a limited sample size so we cannot generalize the findings of this research. This research is conducted only a specific geographical area Bahawalpur, Pakistan. So, there may be a difference in results if the same research is conducted in other areas of the country or even the world. We have focused services sector generally and telecommunication sector particularly to prove the proposed relationships. In contrast, if the same relationships would be applied in the sectors other than telecommunication, the results would have been different.

\section{Recommendations}

This research study provides numerous applications for the existing cellular phones generally and in Pakistan specifically. Brand communication and Brand trust has shown a very significant impact in creating brand loyalty. So, the cellular phones would trigger their 
advertising and promotional activities to multiply their sales which would in turn enhance their profits by making the customers loyal with the help of enhancing their trust and relationship.

In developing countries, the markets are going to be matured like developed countries. It is very difficult for the companies to attract the new customers and retain the old one due to intensive competition for making the above average profits. The simple conventional marketing strategies are not enough without focusing the key areas of development. So, this study provides an opportunity to focus on the key antecedents of brand loyalty.

\section{References}

Aaker, D., \& Keller, K. L. (1990). Consumer Evaluations of Brand Extensions. Journal of Marketing, 54(1),27-41.

Abed Al Aziz, N. (2006). Appearance value in the Middle East, TDC trade, Date 16 May. [Online] Available:www.tdctrade.com/imn/06051603/cosmetics033.htm.

Al-Ashban, A., \& Burney, M. (2001). Key antecedents to cosmetics use among women in Saudi Arabia:Empirical evidence from Saudi Arabia. JISSM, 9, 3- 20.

Ben Amor, Insaf.,\& Francis G. (2009). Influences on free samples usage within the luxury cosmetic market.Direct Marketing: An International Journal, 3(1), 67 - 82.

Business Definition Brand [Online] Available:http://dictionary.bnet.com/definition/Brand+Loyalty.html?tag=col1;rbDictionary (8Apr.2009).

City Mayors. (2009). Cost of living the world's most expensive cities. [Online] Available:http://www.citymayors.com/ features/cost_survey.html. (Retrieved 2009-07-22.).

Clow, M. (2010). Integrated Marketing Communications. Pearson Education, Inc. publishing as Prentice Hall.

Chaudhry, M. D. (2008). Cosmetic industry achieves big growth in the region. Khaleej Times, 22 April.

Cadogan, J. W., \& Foster, B. D. (2000). Relationship Selling and Customer Loyalty: An Empirical Investigation,Marketing Intelligence and Planning, 18(4), 185-199.

Draelos,Z.D.(2007).[Online]Available: http://www.emedicine.com/derm/topic502.htm (Feb 16).

De Ruyter, K., Wetzels, M., \& Van Birgelen, M. (1999). How Do Customers React to Critical Service Encounters: A Cross-sectional Perspective. Total Quality Management, 10(8), 1131-1145.

Duff, M. (2007). Niche Marketing of cosmetics. DSN Retailing Today, 38, 29-35. 
Fornell, C. (1992). A National Customer Satisfaction Barometer: The Swedish Experience. Journal of Marketing,56(Jan), 6-21.

Frings, G. S. (2005). Fashion: From Concept to Consumer (8th Ed.). New Jersey: Pearson/Prentice Hall.

Giunipero, L., \& Daniel J. F. (2001). Purchasing practices in Saudi Arabia - an exploratory analysis.International Journal of Physical Distribution \& Logistics Management, 31, 686-704.

Guthrie, M., Hye-Shin, K., \&Jaehee, J. (2008). The effects of facial image and cosmetic usage on perceptions of brand personality. Journal of Fashion Marketing and Management, 12(2), 164-181.

Gulfnews. (2009). Abu Dhabi and Dubai lead in contributions to GDP. Web.dcci.ae. Retrieved on 2009-07-16.

Howard, J. A., \&Sheth, J. N. (1969). The Theory of Buyer Behavior, New York: John Willy $\&$ Sons.

Kohli, C. \&Thakor, M. (1997). Branding Consumer Goods: Insights from Theory and Practice, Journal of Consumer Marketing, 14(3), 206-219.

Keller, K. L. (2003). Strategic Brand Management: Building, Measuring and Managing Brand Equity. New Jersey: Prentice Hall.

Linda Moore. (2007). [Online] Available: http://cosmeticsuniverse.com

Lau, M. M., Chang, M. S., Moon, K., \& Liu, W. S. (2006). The Brand Loyalty of Sportswear in Hong Kong,Journal of Textile and Apparel. Technology and Management, 5, 1-13.

Lovelock, C. H. (2010). Services Marketing, (4th ed), New Jersey: Prentice Hall.

Lin, M. Y., \& Chang, L. H. (2003). Determinant of Habitual Behavior for National and Leading Brand in China,Journal of Product and Brand Management. 12(2), 94-107.

Marcoux, J. S. (1997). The attitudes underlying preferences of young urban educated polish consumers towards Products made in western countries. Journal of International Consumer Marketing. 9(4), 5-29.

Mayell, H. (2004). As Consumerism Spreads, Earth Suffers, Study Says. National Geographic online. Retrieved September 11, 2008

MMR. (2000). Mass market retailers woo growing teen market, 7 (15), 41.

Meyer, P. (2001). Brands need to understand mindset of echo-boomers in order to survive. Kids Marketing Report, 1(28), 14.

Meneely, L., Amy, B., \& Chris, S. (2009). International Journal of Retail \& Distribution Management. 37(12), $1041-1056$.

Mena Report. (2009). [Online] Available: www.menareport.com. 


\section{Macrothink}

Journal of Public Administration and Governance ISSN 2161-7104 2017, Vol. 7, No. 1

Malhotra, N. K. (2007). Marketing Research: An Applied Orientation (5th ed). New Jersey: Pearson Prentice Hall.

Omar, O. E. (1999). Retail Marketing. Harlow: Pearson Education.

Cochrane, P. (2006). Middle East - The middle ground, Country Survey, SPC June.

Robert, D. (2007). Demand for perfume and cosmetics in the Gulf. Gulf news /21 May.

Rayan, K. (2002). Cosmetics market is booming. Business Today, 19-5-2002.

Russell, R. S., \& Taylor, B. W. (2006). Operation Management: Quality and Competitiveness in a Global Environment (5th ed). New Jersey: John Wiley \& Sons, Inc.

Sproles, G. B., \& Kendall, E. L. (1986). A methodology for profiling consumer decision -making design. The Journal of Consumer Affairs, 20, 267-279.

Sproles, E. K., \&Sproles, G. B. (1990). Consumer decision-making designs as a function of individual learning Designs. The Journal of Consumer Affairs, 24(1), 134-147.

Shaharudin, M. R., Anita, A., Suhardi, W., Shamsul, J., Etty, H., \&Nurazila, A. (2010). The Relationship Between Extrinsic Attributes of Product Quality with Brand Loyalty on Malaysia National Brand Motorcycle/Scooter. Canadian social science, 6, 170-182.

Wong, f. Y., \&Yahyah, S. (2008). Influence of Brand Loyalty on Consumer Sportswear. Int. Journal of Economics and Management, 2, 221-236.

Whittaker, K. (2007). [Online] Available: http://cosmeticsuniverse.com/.

Yoon, S. J., \& Kim, J. H. (2000). An Empirical Validation of a Loyalty Model based on Expectation and Disconfirmation. Journal of Consumer Marketing, 17(2), 120-136.

\section{Copyright Disclaimer}

Copyright for this article is retained by the author(s), with first publication rights granted to the journal.

This is an open-access article distributed under the terms and conditions of the Creative Commons Attribution license (http://creativecommons.org/licenses/by/3.0/). 